\title{
KONTRIBUSI KREDIBILITAS TERHADAP KINERJA PENGAWAS PENDIDIKAN AGAMA ISLAM
}

\author{
Oleh: Muhammad Fazis*
}

\begin{abstract}
This article is a part of study on the contribution of credibility and achievement motivation toward performance of supervisor for Islamic teaching teachers (PAI) at state elementary schools in West Sumatera. Based on preliminary observation, it was found that the performance of the supervisor was low due to some assumed factors, such as low credibility. This study was, therefore, to elaborate such contribution. The formulated hypothesis proposed was credibility contributed toward performance of supervisor for Islamic teaching teachers (PAI) at state elementary schools in West Sumatera. This was a correlational study in which all supervisors for Islamic teaching teachers (PAI) at state elementary schools in West Sumatera were taken as the population. The sample was determenined by following Cochran's formula. Likert's scale questionnaire was used to collect the data after validity and reliability had been achieved. The data then were analysed by employing simple correlational and regressional techniques. The findings showed that the bypothesis was empirically accepted. Credibility contributed 15.2\% toward performance of supervisor for Islamic teaching teachers (PAI) at state elementary schools. Credibility was categorized fair $(65.22 \%$ out of maximum score) and performance of supervisor for Islamic teaching teachers (PAI) at state elementary schools was categorized fair (79.38\% out of maximum score).
\end{abstract}

Kata Kunci: kredibilitas, kinerja, pengawas pendidikan agama Islam, sekolah dasar negeri

\section{PENDAHULUAN}

$\mathrm{P}$ engawasan pendidikan merupakan aspek penting dalam manajemen pendidikan, karena pengawasan pendidikan bertujuan untuk mancegah terjadinya penyimpangan antara perencanaan dengan pelaksanaan dalam penyelenggaraan pendidikan yang pada gilirannya akan mempengaruhi pencapaian tujuan pendidikan. Pengawasan pendidikan dilaksanakan pada semua satuan pendidikan baik pada jenjang pendidikan dasar, menengah maupun tinggi, di samping pe- ngawasan pada pendidikan anak usia dini.

Pelaksanaan pengawasan pada jenjang pendidikan dasar dan menengah serta pendidikan anak usia dini, dilakukan oleh pengawas sekolah yang telah ditunjuk dan ditetapkan oleh pemerintah sebagaimana yang tertera dalam Surat Keputusan Menpan Nomor 118 Tahun 1996 Bab I pasal 1 bahwa Pengawas sekolah adalah Pegawai Negeri Sipil yang diberi tugas tanggung jawab dan wewenang secara penuh oleh pejabat yang berwenang untuk melakukan pengawasan di sekolah dengan melak-

* Penulis adalah Lektor dalam Mata Kuliah Supervisi Pendidikan pada STAIN Batusangkar 
sanakan penilaian dan pembinaan dari segi teknis pendidikan pra sekolah, dasar dan menengah. Pengawasan di sekolah dasar dilaksanakan oleh pengawas sekolah dan pengawas pendidikan agama Islam. Pengawas sekolah melaksanakan pengawasan terhadap mata pelajaran selain mata pelajaran pendidikan agama Islam, sedangkan pengawas pendidikan agama Islam (PPAI) melaksanakan pengawasan terhadap pembelajaran pendidikan agama Islam.

Pelaksanaan pengawasan oleh pengawas pendidikan agama Islam diarahkan pada pelaksanaan kegiatan akademik dan administratif. Pelaksanaan pengawasan kegiatan akademik yaitu pelaksanaan pengawasan terhadap kegiatan proses pembelajaran yang meliputi pengawasan kegiatan guru pendidikan agama Islam dalam merencanakan, melaksanakan, dan mengevaluasi pembelajaran agama Islam. Pelaksanaan pengawasan administratif yaitu pelaksanaan pengawasan terhadap pencatatan kehadiran murid dalam mata pelajaran pendidikan agama Islam, hasil belajar formatif, sumatif dan semester, frekuensi shalat berjemaah siswa disekolah dan jumlah sarana dan prasaran pembelajaran pendidikan agama Islam di sekolah, (Dirjen Bagais, 1999).

Dalam pelaksanaan pengawasan, menurut Gaffar (2001) terdapat beberapa kecenderungan yaitu: (1) sistem pengawasan yang masih amat tradisional, (2) aparat pengawasan mengalami kesulitan dalam melaksanakan tugasya, terutama dalam kaitannya dengan proses pembelajaran, (3) kesimpulan-kesimpulan sebagai temuan pangawasan cenderung administratif, (4) aparat pengawasan cenderung membentuk citra memeriksa, mengusut, mencari kelemahan dan tidak membina, memperbaiki dan membimbing dan (5) aparat pengawasan mengalami kesulitan untuk menerapkan profesionalisme.
Selanjutnya Rachman (2001) mengemukakan, persoalan dan masalah pengawasan/ penilik antara lain; jumlah dan kualitas, keterbatasan anggaran untuk mampu mengunjungi sekolah sekali sebulan, kelangkaan sarana transportasi untuk meninggikan mobilitas menghadapi persoalan-persoalan di lapangan yang mendadak yang memerlukan penanganan segera dan kehidupan sosial ekonomi yang masih memprihatinkan. Jumlah atau rasio pengawas/penilik dengan sasaran, kewibawaan dan mutu pengawasan serta sosial ekonomi menyangkut terbebasnya pengawas dari beban pikiran dan aktivitas untuk mencukupi kebutuhan ekonomi keluarga.

Permasalahan pengawas yang telah dikemukakan di atas diduga juga terjadi pada pengawas pendidikan agama Islam sekolah dasar di Sumatera Barat. Hal ini terindikasi dari fenomena pengawasan yang terlihat sebagai berikut: (1) masih ditemui pengawas pendidikan agama Islam yang tidak melakukan pengawasan sesuai dengan ketentuan yang ditetapkan, kunjungan pengawas pendidikan agama Islam kesekolah hanya sekali dalam satu tahun bahkan ada sekolah yang tidak dikunjungi dalam satu tahun, (2) pengawas bila mengunjungi sekolah hanya berbicara dengan kepala sekolah, menyerahkan format isian yang harus diisi oleh kepala sekolah, seperti; format jumlah siswa baru yang beragama Islam dan jumlah sumber daya pembelajaran pendidikan agama Islam, (3) pengawasan yang dilakukan lebih banyak memberikan instruksi dari pada memberikan bimbingan, kurang kooperatif dengan guru, susah menerima pendapat guru, kurang demokratis, tidak menciptakan suasana kekeluargaan dan mencari-cari kesalahan, (4) pelaksanaan pengawasan kurang teratur dan berkesinambungan, (5) pengawasan yang dilakukan oleh pengawas pendidikan agama Islam di 
sekolah terlihat kurang mendapat respon dari guru. (6) pengawas pendidikan agama Islam pada umumnya berasal dari pejabat struktural yang telah habis masa tugasnya sebagai pejabat struktural dan telah berusia diatas 55 tahun, (7) rasio pengawas dengan guru PPAI yang diawasi adalah $1: 33$, artinya seorang PPAI mengawasi 33 orang guru pendidikan agama Islam dan (8) jarak antara satu sekolah dengan sekolah lain yang diawasi berkisar antara 5 sampai 15 kilometer, (9) guru pendidikan agama Islam belum merasakan peningkatan kemampuan dalam pembelajaran setelah dilakukan pengawasan, (10) pengawas tidak pernah datang untuk monitoring setelah melakukan pengawasan meskipun telah disampaikan kepada guru bahwa akan datang monitoring dan (11) pengawas pendidikan agam Islam belum mampu menjelaskan kepada guru kemampuan pembelajaran yang harus dimiliki guru pendidikan agama Islam agar dapat melaksanakan pembelajaran secara efektif.

Fenomena yang dikemukakan di atas adalah fenomena yang terlihat dalam pelaksanaan pengawasan oleh pengawas pendidikan agama Islam di Sekolah Dasar dan dirasa sangat perlu dilakukan penelitian dalam upaya mengungkap faktor penyebab terjadinya fenomena itu, sehingga dapat dibuat rekomendasi untuk memperbaiki kinerja pengawas pendidikan agama Islam di Sekolah Dasar. Kinerja pengawas pendidikan agama Islam Sekolah Dasar adalah pelaksanaan pekerjaan (performance) yang diperlihatkan oleh pengawas pendidikan agama Islam Sekolah Dasar dalam membimbing dan membina guru pendidikan agama Islam di Sekolah Dasar. Kinerja pengawas pendidikan agama Islam Sekolah Dasar perlu ditingkatkan karena pelaksanaan pengawasan yang efektif akan mempengaruhi keberhasilan pencapaian tu- juan pembelajaran pendidikan agama Islam di Sekolah Dasar.

Morgan (1992) dan Arikunto (1990) menyebutkan bahwa faktorfaktor yang mempengaruhi kinerja antara lain: (1) komitmen, (2) motivasi berprestasi, (3) kemampuan, (4) disiplin kerja, (5) tanggung jawab, (6) suasana kerjasama dan (7) etos kerja. Menurut Dharma (1995), bahwa faktor yang mempengaruhi kinerja adalah kemampuan, sikap, minat, persepsi, struktur tugas, iklim organisasi dan komunikasi serta sistem imbalan. Selanjutnya Anaroga (1992) mengemukakan faktor yang mempengaruhi kinerja adalah daya tarik terhadap pekerjaan, upah, keamanan dan perlindungan kerja, pengetahuan menajemen, lingkungan dan kerjasama, harapan, keterlibatan dalam pengembangan organisasi, perhatian dan kepemimpinan atasan. Sementara itu, Steers (1990) mengungkapkan bahwa kinerja akan dipengaruhi oleh: kemampuan, motivasi, sikap, dan minat terhadap pekerjaan. Mondy dan Premeaux (1995), menyatakan bahwa peningkatan kinerja dapat dilakukan melalui usaha pembinaan sumber daya manusia. Nur (2002) mengemukakan, bahwa pengetahuan menajemen pimpinan akan memberikan kontribusi yang cukup berarti bagi kinerjanya.

Berdasarkan pendapat yang dikemukakan oleh Morgan (1992), Arikunto (1990), Nur (2002), Steer (1990) dan Dharma (1994) di atas, dapat diformulasikan faktor-faktor yang diduga berkontribusi terhadap kinerja PPAI yaitu : (1) motivasi berprestasi, (2) kredibilitas, (3) rekrutmen, (4) lingkungan kerja (5) insentif, (6) persepsi dan (7) struktur tugas serta (8) suasana kerjasama.

Berdasarkan wawancara yang dilakukan dengan pengawas pendidikan agama Islam dan guru-guru pendidikan agama Islam pada sekolah dasar negeri, di Kabupaten Tanah Datar diperoleh 
gambaran sebagai berikut: Dari faktor struktur tugas, pengawas pendidikan agama Islam masih banyak yang tidak tahu akan tugas, fungsi dan tanggung jawabnya, tidak tahu langkah-langkah pengawasan.

Dari sisi kredibilitas terlihat bahwa dalam melakukan pengawasan, pengawas pendidikan agama Islam belum mampu merumuskan program pengawasan, menetapkan tujuan, menetapkan sasaran, memilih pendekatan yang dilakukan, memilih metode /teknik yang digunakan, belum mampu melakukan inovasi metode pengawasan, belum mampu memformulasikan model pengawasan pembelajaran yang efektif untuk masa yang akan datang, belum melibatkan kepala sekolah dan guru senior dalam pelaksanaan pengawasan, belum mampu melakukan evaluasi pelaksanaan pengawasan, belum melakukan monitoring terhadap implementasi saran-saran perbaikan oleh guru pendidikan agama Islam, guru pendidikan agama Islam belum merasakan peningkatan pengetahuan dan perbaikan penampilan pembelajarannya dan hanya merasakan pengawasan baru sebatas mencari kesalahan tanpa mampu mencarikan solusi terhadap permasalahan yang dihapi guru pendidikan agama Islam.

Dari faktor suasana kerja terlihat, pengawas pendidikaan agama Islam tidak memberi tahu guru pendidikan agama Islam sebelum melakukan pengawasan, dalam pelaksanaan pengawasan lebih banyak memberikan instruksi dan memposisikan dirinya selalu lebih tahu, lebih hebat, lebih berkuasa dari pada guru pendidikan agama Islam dan komunikasi antara pengawas pendidikan agama Islam dengan guru terkesan komunikasi antara atasan dan bawahan.

\section{Batasan dan Rumusan Masalah}

Kinerja pengawas pendidikan agama Islam merupakan masalah yang sangat luas karena banyak faktor atau variabel yang mempengaruhinya. Menyadari hal itu dan keterbatasan peneliti dari kemampuan akademik dan sumber daya yang dimiliki, maka peneliti membatasi masalah penelitian ini pada kinerja pengawas pendidikan agama Islam Sekolah Dasar sebagai variabel terikat (Y) dan kredibilitas pengawas pendidikan agama Islam sekolah dasar sebagai variabel bebas (X). Pemilihan variabel bebas dan terikat dalam penelitian ini didasarkan kepada kenyataan bahwa kinerja pengawas pendidikan agama Islam dirasakan masih belum optimal dan kredibilitas (kepercayaan) pengawas pendidikan agama Islam Sekolah Dasar yang ditandai dengan keahlian, atau kepakaran, konsistensi ucapan, tindakan pengawas dan pemenuhan harapan bawahan belum dapat diwujudkan.

Berdasarkan pembatasan masalah di atas, rumusan masalah penelitian ini adalah "apakah kredibilitas berkontribusi terhadap kinerja pengawas pendidikan agama Islam sekolah dasar di Sumatera Barat?".

\section{Defenisi Operasional}

Kredibilitas atau kepercayaan yang dimaksudkan dalam penelitian ini adalah sikap jujur atau kejujuran, mempunyai keahlian, konsisten dan mempunyai komitmen atau sesuai ucapan dengan perbuatan yang diperlihatkan oleh pengawas pendidikan agama Islam dalam melaksanakan pengawasan. Kredibilitas pengawas akan diukur dengan indikator: (1) kejujuran, (2) melihat jauh ke depan, (3) keahlian (4) memberikan inspirasi, (5) adil, (6) memberikan dorongan, (7) konsisten, (8) imajinatif, (9) mau bekerjasama. 
Kinerja yang dimaksud dalam penelitian ini adalah pelaksanaan tugas kepengawasan oleh pengawas pendidikan agama Islam yang diukur melalui indikator: (1) perencanaan supervisi, (2) pelaksanaan supervisi, (3) penilaian pelaksanaan supervisi dan (4) tindak lanjut supervisi.

\section{Tujuan Penelitian}

Tujuan penelitian ini adalah untuk mengungkapkan kontribusi kredibilitas terhadap kinerja pengawas pendidikan agama Islam sekolah dasar negeri di Sumatera Barat.

\section{Metode Penelitian}

Penelitian ini dilakukan dengan menggunakan pendekatan kuantitatif dan jenis penelitian korelasional yang akan medeskripsikan hubungan antara satu variabel dengan variabel lainnya atau dua variabel dengan satu variabel lainnya dengan terlebih dahulu mengklasifikasikan variabel itu atas satu variabel bebas dan satu variabel terikat.

Hubungan masing-masing variabel akan dilihat melalui koefisien korelasi, dengan demikian dapat diketahui sumbangan variabel satu terhadap variabel lain. Sifat penelitian ini adalah deskriptif yaitu penelitian yang menggambarkan suatu objek penelitian dengan apa adanya. Secara lebih operasional penelitian ini akan melihat konstribusi kredibilitas terhadap kinerja pengawas pendidikan agama Islam Sekolah Dasar Negeri di Sumatera Barat.

\section{Populasi dan Sampel}

Populasi dalam penelitian ini adalah semua pengawas pendidikan agama Islam Sekolah Dasar di Sumatera Barat yang berjumlah 112 orang tersebar pada tiga wilayah yaitu wilayah I sebanyak 34 orang, wilayah II sebanyak 37 orang, dan wilayah III sebanyak 41 orang.
Pengambilan sampel dalam penelitian ini dilakukan secara stratified proportional random sampling dengan alasan dapat mempertimbangkan variasi-variasi yang ada pada pupulasi seperti strata pendidikan, lama bertugas atau masa kerja, keterwakilan pada semua strata dan mempunyai kesempatan yang sama untuk menjadi sampel. Proses pengambilan sampel dalam penelitian ini dilakukan malalui tiga tahap yaitu: (1) identifikasi karakteristik pupulasi, (2) menentukan besarnya sampel dan (3) menentukan subjek. Untuk menentukan besarnya sampel digunakan rumus Cochran (1974).

\section{Alat Pengumpul Data}

Instrumen yang dugunakan untuk mengumpulkan data dalam penelitian ini adalah angket model skala Likert. Sugiyono (1994 : 73) mengatakan 'skala Likert dapat digunakan untuk mengukur sikap, pendapat, dan persepsi seorang atau sekolompok orang tentang fenomena sosial'. Disebabkan yang akan diukur dalam penelitian ini pendapat responden tentang kinerjanya maka skala Likert dapat digunakan sebagai alat pengumpul data. Penggunaan angket model skala Likert dengan menyediakan lima alternatif jawaban yaitu : selalu (SL), sering (SR), kadang-kadang (KD), jarang (JR) dan tidak pernah (TP). Pernyataan yang diajukan dalam bentuk pernyataan positif dan negatif. Pernyataan positif diberi bobot 5 bagi responden yang menyatakan selalu, 4 bagi yang menyatakan sering, 3 bagi yang menyatakan kadang-kadang, 2 bagi yang menyatakan jarang dan 1 bagi yang menyatakan tidak pernah. Sebaliknya pernyataan negatif diberi bobot sebagai berkut: pernyataan responden tidak pernah diberi bobot 5, jarang diberi bobot 4, kadang-kadang diberi bobot 3, sering diberi bobot 2 dan selalu diberi bobot 1 . 
Penyusunan instrumen pada masing-masing variabel dilakukan dengan langkah-langkah sebagai berikut: (1) pembuatan kisi-kisi instrumen berdasarkan indikator variabel, (2) menyusun butir-butir pernyataan yang sesuai dengan indikator-indikator variabel, (3) melakukan analisis rasional untuk melihat kesesuaian dengan indikator serta ketepatan penyusunan angket dari segi bahasa dan aspek yang diukur, (4) uji coba instrumen untuk mengetahui validitas dan realibilitas instrumen.

\section{Teknik Pengumpulan dan Analisis Data}

Pengumpulan data dilakukan dengan cara menemui subjek penelitian secara langsung. Angket diisi langsung oleh subjek penelitian di Kandepag Kabupaten/ Kota sesuai dengan lokasi penelitian dan angket segera dikembalikan pada waktu itu juga. Dengan perkataan lain peneliti menunggu subjek penelitian mengisi angket sambil memberikan penjelasan kepada subjek penelitian bila ada pernyataan dalam angket yang diragukannya. Setelah semua subjek penelitian menyerahkan angket yang telah diisi, dilakukan pengecekan kalau ada butir pernyataan yang tidak dijawab oleh subjek penelitian.

Data penelitian dianalisis dengan menggunakan teknik regresi dan korelasi. Analisis data dilakukan dengan bantuan analisis data statistik program SPSS versi 11. Langkah-langkah analisis tersebut adalah sebagai berikut: pengujian persyaratan analisis, pengujian hipótesis penelitian ini menggunakan uji probabilitas (p) dengan level of significan $(=0,05)$ atau pada taraf kepercayaan $95 \%$. Pengujian ini didasarkan atas nilai signifikansi dari setiap koofesien korelasi antara variable bebas $(\mathrm{X})$ dengan variabel terikat $(\mathrm{Y})$. Hipotesis diuji dengan menggunakan teknik korelasi dan regresi linier seder- hana untuk mengetahui besarnya kontribusi variabel bebas terhadap variabel terikat $(\mathrm{Y})$.

\section{HASIL PENELITIAN DAN PEMBAHASAN}

\section{Kredibilitas}

Hasil pengolahan data tentang Kredibilitas Pengawas menunjukan, skor terendah 107 dan skor tertinggi 257 dari skor maksimum ideal 275. Hasil perhitungan dari distribusi data juga menunjukan bahwa rata-rata (mean) sebesar 179,35, simpangan baku (standar deviasi) 38,373, median 179 dan mode 150. Berdasarkan data tersebut terlihat rata-rata dan median tidak jauh berbeda. Hal ini membuktikan bahwa skor variabel Kredibilitas Pengawas berdistribusi normal.

Dari data yang diperoleh, rata-rata tingkat pencapaian kredibilitasi 65,22\% dari skor maksimum ideal dan masuk dalam kategori cukup. Dengan demikian dapat dikatakan bahwa secara umum kredibilitas pengawas pendidikan agama Islam sekolah dasar di Sumatera Barat berada pada kategori cukup.

\section{Kinerja Pengawas}

Pengelolaan data tentang kinerja pengawas menunjukan bahwa skor terendah 76 dan skor tertinggi 117 dari skor maksimum ideal 125 . Hasil perhitungan dari distribusi data menghasilkan rata-rata (mean) 101,55, simpangan baku (standar deviasi) 9,58, median 101 dan modus 109. Perhitungan tersebut menunjukan bahwa skor kinerja pengawas berdistribusi normal, karena rata-rata (mean) dan mediannya tidak jauh berbeda.

Dari perhitungan, tingkat pencapaian responden diperoleh skor variabel kinerja pengawas pendidikan agama Islam sekolah dasar negeri sebesar 
$79,384 \%$ dari skor maksimum ideal. Ini menggambarkan bahwa kinerja pengawas pendidikan agama Islam sekolah dasar negeri termasuk kategori cukup.

\section{Pengujian Persyaratan Analisis}

Pengujian hipotesis penelitian dilaksanakan dengan menggunakan satatistik parametrik dengan teknik analisis korelasi dan regresi, namun sebelum analisis itu digunakan terlebih dahulu ada beberapa persyaratan yang harus dipenuhi. Menurut Irianto(1998) ada tiga persyaratan yang harus dipenuhi dalam menggunakan statistik parametrik yaitu: (1) sampel diambil secara acak, (2) distribusi data harus normal, dan (3) persamaan regresinya harus linier. (Irianto, 1988).

Persyaratan pertama, yaitu sampel harus diambil secara acak telah terpenuhi saat pengambilan sampel yaitu dengan menggunakan teknik stratified random sampling. Sedangkan persyaratan normalitas dan linieritas diketahui setelah penelitian dilaksanakan dengan cara mengolah data menggunakan program statistik. Persyaratan kedua, yaitu uji normalitas. Melalui pengolahan data dengan menggunakan uji Kolmogorov Smirnov Test menunjukan bahwa distribusi data penelitian normal. Hasilnya terlihat bahwa asymptotic significance keseluruhan variabel lebih besar dari probabilitas 0,05. Dengan demikian dapat disimpulkan bahwa seluruh variabel berdistribusi normal.

Persyaratan ketiga yaitu uji linieritas. Berdasarkan hasil pengolahan data diperoleh hasil analisis pada Tabel berikut.

Tabel 1. Hasil Analisis Varians Kredibilitas terhadap Kinerja Pengawas

\begin{tabular}{|c|c|c|c|c|c|}
\hline $\begin{array}{c}\text { Sourc } \\
\text { e }\end{array}$ & $\begin{array}{c}\text { Sum of } \\
\text { Square } \\
\text { S }\end{array}$ & Df & $\begin{array}{r}\text { Mean } \\
\text { Squar } \\
\text { e }\end{array}$ & $\begin{array}{c}\text { F } \\
\text { Rasio }\end{array}$ & Sig. \\
\hline $\begin{array}{l}\text { Regr } \\
\text { essio }\end{array}$ & $\begin{array}{c}585,53 \\
8\end{array}$ & 1 & $\begin{array}{r}585,5 \\
38\end{array}$ & 7,344 &, $010^{\mathrm{a}}$ \\
\hline
\end{tabular}

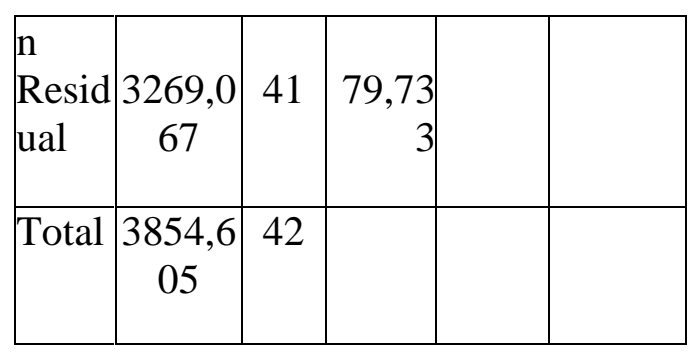

Pada tabel di atas menunjukan bahwa $\mathrm{F}$ hitung untuk keberartian model regresi sebesar 7,344 > dari $\mathrm{F}$ tabel pada $\alpha 0,05 \quad(3,88)$. Dengan demikian berarti persamaan regresi linier sederhana $=84,107+0,097 \mathrm{X}_{1}$ dapat digunakan sebagai syarat untuk memberikan kesimpulan yang menjelaskan hubungan Kredibilitas dengan Kinerja Pengawas.

\section{Pengujian Hipotesis}

Berdasarkan hasil pengujian persyaratan analisis menunjukan bahwa skor setiap variabel penelitian telah memenuhi syarat untuk dilakukan pengujian statistik lebih lanjut. Sehubungan dengan hal tersebut di atas ada tiga hipotesis yang akan diuji secara empirik, yaitu kredibilitas berkontribusi terhadap kinerja pengawas pendidikan agama Islam sekolah dasar negeri di Sumatera Barat. Rangkuman hasil analisis sehubungan dengan hipotesis tersebut dapat dilihat pada tabel berikut ini.

Tabel 4. Hasil Analisis Korelasi dan Regresi serta Uji t antara Kredibilitas dengan Kinerja Pengawas Pendidikan

Agama Islam di Sumatera Barat

\begin{tabular}{|c|c|c|c|}
\hline $\begin{array}{c}\text { Korelasi } \\
\left(\mathrm{r}_{\mathrm{y} 1}\right)\end{array}$ & $\begin{array}{c}\text { Koefisien } \\
\text { Determinasi } \\
\left(\mathrm{r}^{2} \mathrm{y}_{1}\right)\end{array}$ & $\begin{array}{c}\mathrm{t} \\
\text { hitung }\end{array}$ & Sig. \\
\hline 0,390 & 0,152 & 2,710 & 0,010 \\
\hline
\end{tabular}

Berdasarkan tabel di atas diketahui bahwa korelasi antara kredibilitas dengan kinerja pengawas pendidikan agama Islam dasar negeri sebesar 0,390. Uji keberartian korelasi pada taraf $\alpha=$ 
0,05 diperoleh $\mathrm{r}$ tabel 0,308 , ternyata $\mathrm{r}$ hitung > dari $\mathrm{r}$ tabel $(0,390>0,308)$. Dengan demikian dapat disimpulkan bahwa terdapat hubungan yang positif antara kredibilitas dengan kinerja pengawas pendidikan agama Islam sekolah dasar negeri di Sumatera Barat. Hal ini juga berarti bahwa baiknya kredibilitas pengawas pendidikan agama Islam sekolah dasar negeri di Sumatera Barat maka dapat pula meningkatkan kinerja pengawas pendidikan agama Islam sekolah dasar negari di Sumatera Barat.

Hasil analisis juga menunjukan bahwa adanya sumbangan yang berarti dari kredibilitas terhadap kinerja pengawas pendidikan agama Islam sekolah dasar negari di Sumatara Barat. Hal ini terlihat dari hasil perhitungan yang menunjukan nilai t hitung sebesar 2,710 sedangkan Sig. $0,010<0,05$. Dilihat dari koefisen determinasi sumbangan kredibilitas pengawas pendidikan agama Islam sekolah dasar negeri di Sumatera Barat hanya 15,2\%.

Berdasarkan hasil analisis di atas dapat disimpulkan bahwa terdapat hubungan yang positif dan berarti antara kredibilitas dengan kinerja pengawas pendidikan agama Islam sekolah dasar negari di Sumatara Barat. Hal ini berarti bahwa $\mathrm{H}_{0}$ ditolak dan $\mathrm{H}_{\mathrm{i}}$ diterima pada taraf signifikansi 5\%.

\section{PEMBAHASAN}

Berdasarkan hasil analisis data dari ketiga variabel ternyata tiga hipotesis yang diajukan dalam penelitian ini dapat diterima, baik secara sendiri-sendiri maupun secara bersama-sama. Artinya dari proses analisis regresi sederhana maupun analisis regresi ganda terbukti bahwa, terdapat kontribusi yang signifikan dari kredibilitas dan motivasi berprestasi baik sendiri-sendiri maupun bersma-sama terhadap kinerja pengawas pendidikan agama Islam sekolah dasar negeri di Sumatera Barat. Secara lebih rinci temuan penelitian ini dapat penulis paparkan sebagai berikut :

\section{Temuan Pertama}

Hasil analisis data menunjukan tingkat pencapaian variabel kredibilitas sebesar $65,22 \%$, variable motivasi berprestasi 77,96, dan variable kinerja pengawas pendidikan agama Islam sekolah dasar negeri 79,38\%. Dari hasil analisis dapat dikatakan bahwa variable, kredibilitas , motivasi berprestasi dan kinerja berada dalam kategori cukup.

\section{Temuan Kedua}

Hasil analisis memberikan gambaran bahwa terdapat korelasi yang signifikan antara kredibilitas dengan kinerja pengawas pendidikan agama Islam sekolah dasar negeri sebesar 0,390. Sementara itu kredibilitas memberikan konstribusi terhadap kinerja pengawas pendidikan agama Islam sekolah dasar negeri sebesar $15,2 \%$.

Temuan ini membuktikan bahwa kredebilitas mempunyai kontribusi untuk meningkatkan kinerja pengawas pendidikan agama Islam sekolah dasar negeri di Sumatera Barat, walaupun dari pencapaian responden, kredibilitas pengawas pendidikan agama Islam sekolah dasar negeri di Sumatera Barat baru dalam kategori cukup. Data dari temuan ini menunjukkan, jika kredibilitas pengawas pendidikana agam Islam sekolah dasar negeri di Sumatera Barat baik maka kinerjanya meningkat.

Hasil penelitian juga mengungkapkan bahwa dugaan kinerja pengawas pendidikan agama Islam sekolah dasar negeri di Sumatera Barat yang rendah karena kredibilitasnya yang rendah tidak terbukti dan penelitian ini membuktikan bahwa rendahnya kinerja pengawas pendidikan agama Islam sekolah dasar negeri di Sumatera Barat bukan karena kredibilitas tetapi diduga dari faktor lain yang tidak 
terungkap dalam penelitian ini. Nur (1992) mengatakan bahwa kredibilitas akan terwujud bila seseorang memperlihatkan perilaku bisa dipercaya (trustworthiness) dan ahli (expertness)“. Dengan demikian dapat dikatakan, kepercayaan dan keahlian merupakan faktor yang dapat meningkatkan kredibilitasi pengawas pendidikan agama Islam sekolah dasar negeri di Sumatera Barat.

Hasil penelitian ini menguatkan penelitian yang dilakukan sebelumnya oleh Agustiar Syah Nur (2002) yang menyatakan bahwa kredibilitas berkontribusi terhadap kepemimpinan. Arwildayanto (2002) kredibilitas memberikan kontribusi terhadap budaya kerja. Dengan demikian baik dari kajian teori, penelitian yang relevan dan penelitian yang dilakukan penulis membuktikan bahwa kredibilitas merupakan faktor penting untuk meningkatkan kinerja pengawas pendidikan agama Islam sekolah dasar negeri sehingga faktor ini perlu dan penting untuk ditingkatkan agar kinerja pengawas pendidikan

\section{DAFTAR RUJUKAN}

Agus Dharma. 1984. Gaya Kepemimpinan yang Efektif Bagi Para Menejer. Bandung: Sinar Baru.

Agus Irianto,. 1989. Statistik Pendidikan. Depdikbud. Dirjen Dikti. Jakarta: Proyek Pengembangan LPTK.

Agustiar Syah Nur 1992. "Komunikasi, Kredibilitas Komunikator dan Aplikasinya dalam Pengelolaan Pendidikan". Wawasan Ilmu Pengetahuan, Teknologi dan Seni 1 (1) : 1-15.

2002. Kredibilitas Penghulu dalam Kepemimpinan Adat Minangkabau. Padang: Penerbit Lubuk Agung. agama Islam sekolah dasar negeri di Sumatera Barat lebih meningkat.

\section{KESIMPULAN}

Berdasarkan hasil penelitian yang telah dikemukakan di atas dapat ditarik kesimpulan bahwa kredibilitas berkontribusi terhadap kinerja pengawas pendidikan agama Islam sekolah dasar negeri di Sumatera Barat. Hal ini berarti semakin baik kredibilitas pengawas pendidikan agama Islam maka semakin baik pula kinerja pengawas pendidikan agama Islam sekolah dasar negeri di Sumatera Barat.

Penelitian ini juga menemukan bahwa variabel prediktor yang diteliti yakni kredibilitas memberikan kontribusi yang berarti terhadap kinerja pengawas pendidikan agama Islam sekolah dasar negeri di Sumatera Barat. Oleh karena itu perlu lebih diperhatikan variabel prediktor ini untuk ditingkatkan agar pengawas pendidikan agama Islam sekolah dasar negeri merasa diperhatikan dan dihargai dalam melaksanakan tugasnya.

Arwildayanto. 2002. Persepsi Guru tentang Manajemen Konflik dan Kredibilitas Kepala Sekolah terhadap Budaya Kerja Guru SMU Negeri di Kabupaten Tanah Datar. Tesis tidak diterbitkan. Padang: Program Pascasarjana Universitas Negeri Padang

Cochran.,W.G 1977. Sampling Techniques. New Delhi: Weseley Easterm Private limited.

Depag. 1999. Petunjuk Pelaksanaan Supervisi Pendidikan. Jakarta: Dirjen Binbagais. ,. 2004. Pedoman Pengembangan Administrasi dan Supervisi Pen- 
didikan. Jakarta; Dirjen Kelembagaan Agama Islam.

Dirjen Bagais. 2000. Pedoman Pelaksanaan Supervisi Pendidikan. Jakarta. Depag RI.

Fakry Gaffar. 2001. Pengawasan Kependidikan Profesionalisme : Visi, Misi dan Strategi. Forwas 1 (x) : 12-16.

G. Simon Devung. 1988. Pengantar Ilmu Administrasi dan Manajemen. Jakarta: Depdikbud. Dirjen Pendidikan Tinggi PLPTK.

Ibrahim Bafadal. 1992. Supervisi Pengajaran: Teori dan Aplikasinya dalam Membina Profesional Guru. Jakarta: Bumi Aksara.

Jalius Jama. 2005. Bahan Kajian Perkuliahan Pengawasan dan Supervisi Pendidikan. Universitas Negeri Padang

Komaruddin. 1992. Manajemen Pengawasan Kualitas Terpadu. Jakarta.Rajawali Pers.
M.Dachnel Kamars. 2004. Administrasi Pendidikan; Teori dan Praktek. Padang: Suryani Indah.

Nana Sudjana 1982. Metode Statistik. Bandung. Penerbit Trasito. „. 1982. Dasar-dasar Penelitian Hasil Belajar. Jakarta: Sera Jaya.

Nanang Fatah, 1996. Landasan Manajemen Pendidikan. Bandung: Rosda Karya.

Panji Anoraga. 1992. Psikologi Kerja. Jakarta: Rineka Cipta.

Rusli Ruslan. 2001. Sistem Pengawasan Bidang Teknis. Forwas 1 (x) : 35-37.

Steer, M. 1986. Efektifitas Organisasi. Terjemahan oleh Surya. Jakarta: Erlangga.

Suharsimi Arikunto, 1997. Prosedur Penelitian. Jakarta: Rineka Cipta. . 1988. Organisasi dan Administrasi Pendidikan Teknologi dan Kejuruan. Jakarta: Depdikbud. P2LPTK. 